\title{
Anti-CD8 Monoclonal Antibody
}

National Cancer Institute

\section{Source}

National Cancer Institute. Anti-CD8 Monoclonal Antibody. NCI Thesaurus. Code C112888.

Any monoclonal antibody directed ag ainst the cell surface glycoprotein CD8, regardless

of the antibody type. 